University of Nebraska - Lincoln

DigitalCommons@University of Nebraska - Lincoln

\title{
Provenance of Pleistocene sediments in the ANDRILL AND-1B drillcore: Clay and heavy mineral data
}

\author{
Giovanna Giorgetti \\ Università di Siena, giorgettig@unisi.it \\ Franco M. Talarico \\ Università di Siena, talarico@unisi.it \\ Sonia Sandroni \\ Università di Siena, sandroni@unisi.it \\ Antonio Zeoli \\ Università di Siena
}

Follow this and additional works at: https://digitalcommons.unl.edu/andrillrespub

Part of the Environmental Indicators and Impact Assessment Commons

Giorgetti, Giovanna; Talarico, Franco M.; Sandroni, Sonia; and Zeoli, Antonio, "Provenance of Pleistocene sediments in the ANDRILL AND-1B drillcore: Clay and heavy mineral data" (2009). ANDRILL Research and Publications. 53.

https://digitalcommons.unl.edu/andrillrespub/53

This Article is brought to you for free and open access by the Antarctic Drilling Program at DigitalCommons@University of Nebraska - Lincoln. It has been accepted for inclusion in ANDRILL Research and Publications by an authorized administrator of DigitalCommons@University of Nebraska - Lincoln. 
Published in Global and Planetary Change 69:3 (November 2009), pp. 94-102; doi: 10.1016/j.gloplacha.2009.03.018 ; Cenozoic Antarctic glacial history, EGU meeting (http://meetings.copernicus.org/egu2008/); International Geological Congress (IGC) Conference (http://www.33igc.org/)

Copyright (C) 2009 Elsevier B.V. Used by permission.

\title{
Provenance of Pleistocene sediments in the ANDRILL AND-1B drillcore: Clay and heavy mineral data
}

\author{
Giovanna Giorgetti, ${ }^{1}$ Franco Talarico, ${ }^{1}$ Sonia Sandroni, ${ }^{2}$ and Antonio Zeoli ${ }^{2}$ \\ 1. Dipartimento di Scienze della Terra, Università di Siena, via del Laterino 8, 53100 Siena, Italy \\ 2. Museo Nazionale dell' Antartide, Sezione Scienze della Terra, Università di Siena, via del Laterino 8, 53100 Siena, Italy \\ Corresponding author - G. Giorgetti, tel 390577 233830, fax 390577 233938, email giorgettig@unisi.it
}

\begin{abstract}
The cryosphere in the McMurdo Sound region has undergone significant modifications during the last $1 \mathrm{Ma}$. Consequently, the sedimentary sequences underlying the modern McMurdo Ice-Shelf provide geological data to reconstruct variations in transport and depositional mechanisms of terrigenous material due to variations in ice sheet extension, grounding line position and main icestream flow directions during glacial and interglacial periods. The present study aims to investigate the clay and heavy mineral assemblages of the late Pleistocene subglacial and glaciomarine sediments recovered during the ANDRILL-McMurdo Ice Shelf Project in Windless Bight (South of Ross Island). The analyses show that the sediments are a mix of detritus from the McMurdo Volcanic Group (MVG) and the Transantarctic Mountains (TAM) from the south and west. MVG-derived minerals prevail with respect to TAM-derived minerals. The down-core mineralogical variations are determined by changes in the source rocks and the sedimentary processes. Sediments at the drill site are nourished by ice coming from the South which delivered rocks from the McMurdo Volcanic region; the enrichment of a TAM component in massive diamictites testifies that the ice sheet collected debris from the Transantarctic Mountains. When open marine conditions prevailed, only sediments from a local source (i.e. McMurdo volcanics) were deposited.
\end{abstract}

Keywords: provenance, clay minerals, heavy minerals, ANDRILL, Ross Sea, Antarctica

\section{Introduction}

The mineralogy of glacial and glaciomarine sediments deposited on the Antarctic continental margin is a powerful tool to understand the subglacial and glaciomarine processes which occur in subglacial, ice shelf, and open ocean environments.

Physical weathering and erosion on land produce mineral associations which reflect the composition of the source rocks. Since cold and arid climatic conditions prevailed from at least the Pliocene, clay mineral variations in Pleistocene Antarctic marine sediments directly indicate changes of the source areas which in turn mirror the glacial dynamics on the continent (Ehrmann et al., 1992; Petschick et al., 1996; Ehrmann, 1998; Lucchi et al., 2002; Hillenbrand and Ehrmann, 2005; Damiani et al., 2006). Heavy mineral assemblages in Antarctic marine sediments can also be successfully used to identify different source areas and to reconstruct the dynamics of ice sheets (Angino and Andrews, 1968; Ehrmann and Polozek, 1999; Polo, 2000; Neumann, 2001; Damiani and Giorgetti, 2008). The aim of this paper is to reconstruct the ice dynamics in the McMurdo region (western Ross Sea) through an integrated clay and heavy mineral study of Pleistocene sediments from a core collected beneath the McMurdo/Ross Ice Shelf in Windless Bight, south of Ross Island (Naish et al., 2007). This core (AND-1B) recovered a geological record which allows to decipher Antarctic climatic, glacial and tectonic history during the last $13 \mathrm{Ma}$ The sediments from AND-1B record the repeated advance and retreat of grounded ice, and the information obtained from their study will contribute to a better understanding of the dynamics of the Antarctic Ice Sheet (AIS) and the Ross Ice Shelf/Sheet system (Naish et al., 2007). During the Pliocene, the Ross ice sheet is considered to be dynamic, and icefree conditions may have prevailed in the Ross Embayment (Barrett and Orombelli, 1999; Naish et al., 2007). From the Middle Pleistocene to present the ice sheet became stable under colder conditions (Barrett and Orombelli, 1999; Naish et al., 2007). However the dynamics of the Ross ice sheet during the Quaternary remain unclear.

Since detrital minerals mirror the nature of the source areas, their variations in sediments deposited in this keyarea provide a record of the evolution of the Ross ice sheet/ shelf, which will allow to reconstruct the dynamics of the ice masses. In this frame, we focus our study on the upper part of the core which is younger than $1 \mathrm{Ma}$ in order to improve the understanding of the Late Pleistocene variation in ice dynamics in the McMurdo area.

\section{Regional setting}

The McMurdo Ice Shelf (MIS) project drill site (Naish et al., 2007) is located in Windless Bight under the McMurdo-Ross ice shelf (MRIS) (Figure 1). Almost two-third of the Ross ice 


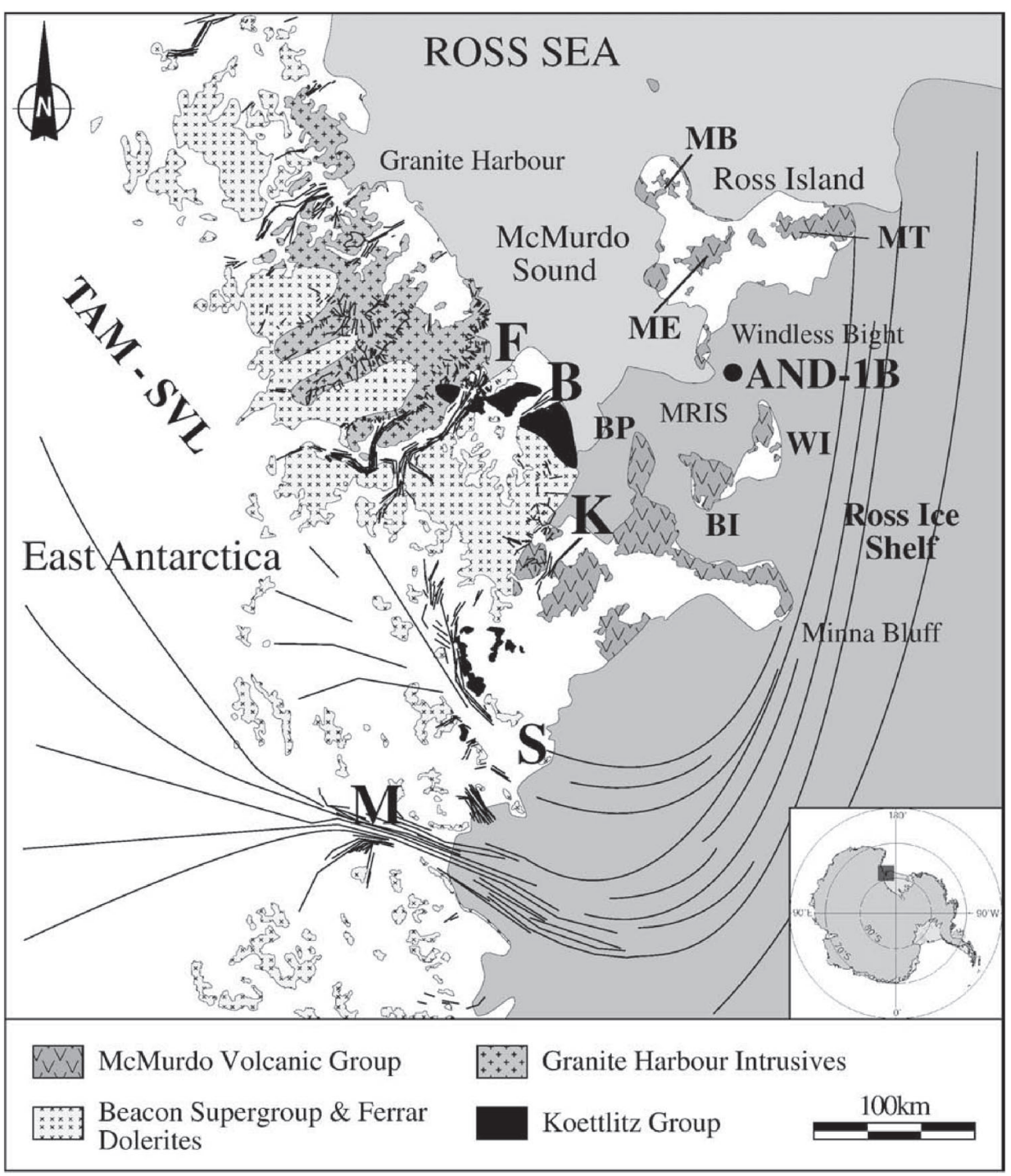

Figure 1. Map of the McMurdo Sound area. The filled grey square on Antarctica refers to the enlarged picture.

Dot: drill site.

MRSI: McMurdo/Ross ice shelf.

TAM-SVL: Transantarctic Mountains Southern Victoria Land.

F: Ferrar Glacier;

B: Blue Glacier;

K: Koettlitz Glacier;

S: Skelton Glacier;

M: Mulock Glacier;

BP: Brown Peninsula;

WI: White Island;

BI: Black Island;

ME: Mt Melbourne;

MB: Mt Terror;

MB: Mt Bird.

Koettlitz Group mainly outcrops between the Skelton and the Koettlitz area. Lines indicate the modern ice flow (see [Bentley, 1998; Denton and Hughes, 2000).

shelf is nourished by ice streams draining the West Antarctic Ice Sheet (WAIS); however, south of Ross Island, East Antarctic discharge feeds the MRIS (Bentley, 1998). The Koettlitz Glacier flows into the MRIS west of Brown Peninsula. The Skelton and the Mulock glaciers terminate south of Minna Bluff. According to Kellogg et al. (1996) and Denton and Hughes (2000, 2002), ice from Mulock Glacier flew around Minna Bluff before being advected in Southern McMurdo Sound during the Last Glacial Maximum; Koettlitz Glacier withdrew behind its present position; ice flew down Ross Island towards the north and south-west. At present, with the ice shelf grounded south of Minna Bluff, glaciers from the Transantarctic Mountains (TAM), such as Koettlitz, Blue and Ferrar glaciers, discharge into McMurdo Sound.

The geology of the area surrounding the AND-1B drill site has been the subject of numerous papers (Sandroni and Talarico, 2006, and bibliography therein). In a regional framework, Cenozoic sub-alkaline volcanic rocks of the McMurdo Volcanic Group (MVG) (Kyle, 1990) constitute Ross Island to the East, White Island and Black Island, Brown Peninsula and Minna Bluff to the South (Figure 1). Mt. Erebus, an active volcano, Mt. Bird and Mt. Terror are the main volcanic centers on Ross Island. The lavas range from basanite to phonolite; phenocrysts in these volcanic rocks are anorthoclase, olivine, titanomagnetite, various spinels, plagioclase, kaersutite, titanoaugite, and a rare Ti-rich silicate (rhönite) (Kyle and Price, 1975). The volcanic centers of White Island, Black Island and Brown Peninsula erupted basanites, phonolites, trachybasalts, and trachytes (LeMasurier and Thomson, 1990) with olivine, kaersutite, titanoaugite, plagioclases, and various oxides as seriate phenocrysts. West of the drill site, the TAM in southern Victoria Land are built up by a Late-Proterozoic crystalline basement (BC) intruded by magmatic rocks of the Granite Harbour Intrusive Complex (GHI) (Smillie, 1992, and references therein). North of Koettlitz Glacier, the crystalline basement consists of metasedimentary rocks of greenschistamphibolite facies and marbles (Koettlitz Group). Biotitegarnet schists, amphibolites, gneisses, and diopside/grossular-bearing marbles are the dominant rock types (Blank et al., 1963; Findlay et al., 1984). Limestones, argillites, conglomerates, calcsilicates, and basaltic pillow lavas metamorphosed at very-low metamorphic grade outcrop in the Skelton-Mulock Glacier area (Cook and Craw, 2002). Paleozoic-Mesozoic rocks overlie the basement rocks: siltstones and arkoses of Devonian-Jurassic age (Beacon Supergroup, BS) (Harrington, 1965) are intruded by Jurassic dolerites (Ferrar dolerites) of the Ferrar Supergroup, which also includes tholeiitic basalts (Kirkpatrick basalts) (Gunn, 1962; Brotzu et al., 1988). The 

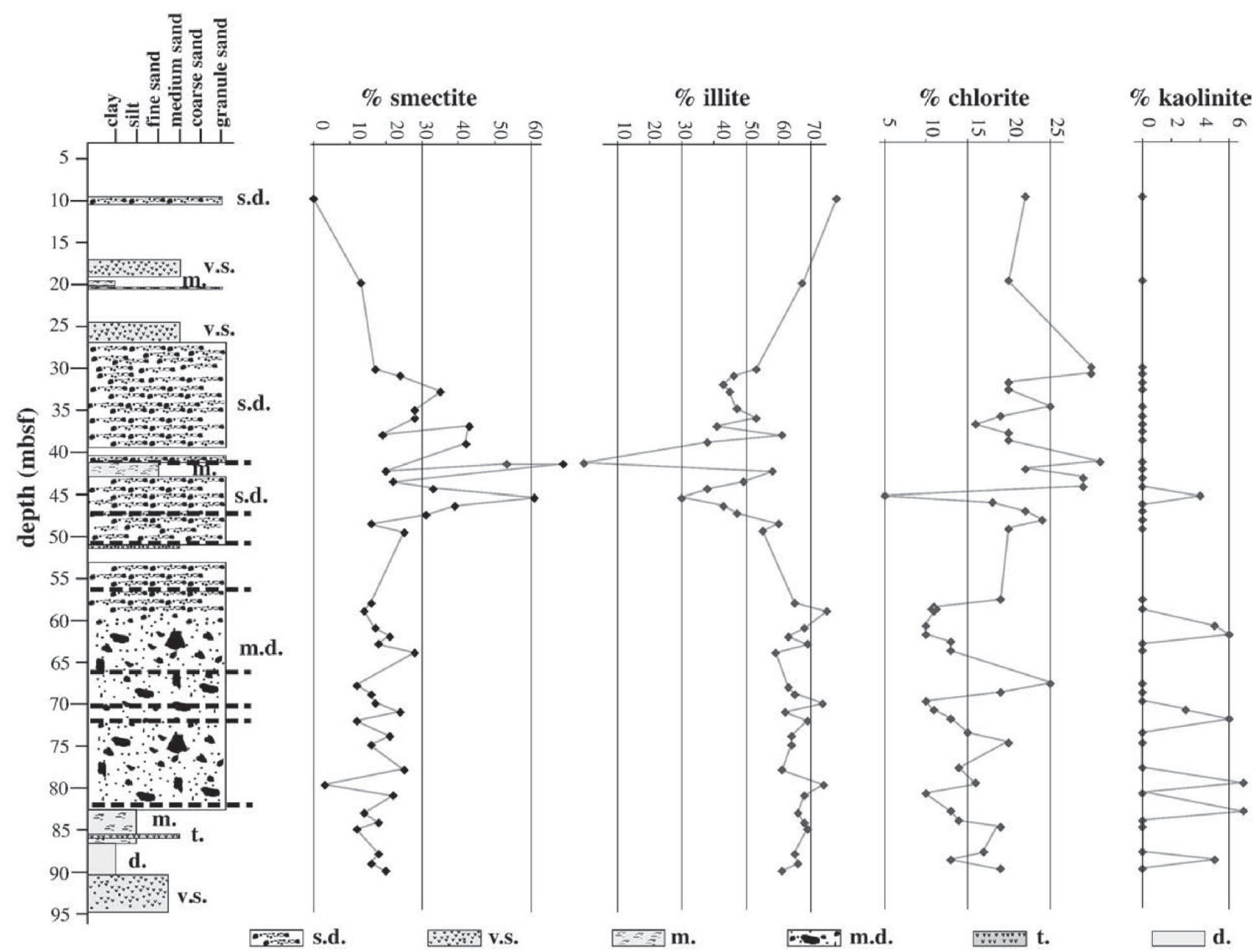

Figure 2. Down-core variations of clay mineral contents in the AND-1B core. A schematic lithological core log is reported (modified from Krissek and the ANDRILL-MIS Science Team, 2007). s.d.: stratified diamicton; v.s.: volcanic sand; m.: mudstone (w/o disperse clasts); m.d.: massive diamicton; t.: tephra layer; d.: diatomites (with mudstone). mbsf: meters below sea floor. Dashed lines indicate the Glacial Surfaces of Erosion (GSE).

doleritic sills intrude both the BS and pre-Devonian basement rocks. Augite, pigeonite, orthopyroxenes, plagioclase are the main mineral phases in the sills (Elliot et al., 1995).

\section{Material and methods}

The AND-1B core (Figure 1) was drilled during the austral summer 2006/07 through an 82 m thick ice-shelf; the MIS drill site is situated South of Ross Island $\left(77.89^{\circ} \mathrm{S}, 167.09^{\circ} \mathrm{E}\right)$ in a basin that formed in response to Quaternary volcanic loading by Ross Island, superimposed on regional subsidence associated with Neogene extension (Naish et al., 2007). The $1284.84 \mathrm{~m}$-long core recovered a non-continuous Pleistocene-Miocene sequence comprising subglacial, glaciomarine, volcanogenic and biogenic sediments. A felsic tephra at $85.5 \mathrm{~m}$ below sea floor (mbsf) has been dated at $1.014 \mathrm{Ma}$ (Wilson and the ANDRILL-MIS Science Team, 2007); this datum coupled with preliminary paleontological and magnetostratigraphic data indicate that the upper ca. $85 \mathrm{~m}$ of the core is of Quaternary age. The sediments mainly comprise massive diamictites attributed to subglacial deposition (see Krissek and the ANDRILL-MIS Science Team, 2007); stratified diamictites are interpreted to record both subglacial deposition and sub-ice shelf sedimentation associated with debris-flow deposition, rainout of basal debris, reworking by marine currents and glacial outwash. Mudstones without dispersed clasts and volcanoclastic sandstones record a hemipelagic sedimentation in a marine environment either distal or proximal from the grounding line. Below $82 \mathrm{mbsf}$ in situ volcanic deposits and diatomites associated with mudstones occur; these deposits are interpreted to record pelagic sedimentation in an open marine environment (Krissek and the ANDRILL-MIS Science Team, 2007).

Based on core description, the ANDRILL sedimentology team (Krissek and the ANDRILL-MIS Science Team, 2007) proposed a lithostratigraphic interpretation. Above $82.47 \mathrm{mbsf}$ the core is dominated by diamictites intercalated by thin sequences of mudstones, volcanic sandstones, and conglomerates. The diamictite is massive to stratified (in the upper part) and records periods of grounded ice with episodes of proximal glaciomarine sedimentation (Figure 2) (McKay et al., 2009). Below $82.74 \mathrm{mbsf}$, the core recovered sandstones, mudstones, diatomites and diamictites with variable volcanic content; the diamictite is overlain by mudstones and biosiliceous mudstones which represent an ice distal (proglacial) and seasonal open marine setting. Several unconformities have been recognized throughout the core and they have been interpreted as Glacial Surfaces of Erosion (GSE) (Krissek and the ANDRILL-MIS Science Team, 2007); they are interpreted as boundaries of facies sequences which represent repeated grounded-ice advance and retreat across the continental shelf. In the upper part of the core, eight GSE have been reported (Figure 2).

Since we focus our research on the Late Pleistocene section, we sampled the upper $90 \mathrm{~m}$ of the core. A total of 47 samples have been processed. We avoided to sample volcanic rocks and tephra.

The clay fraction separation and analyses were performed following standard procedures (Ehrmann et al., 1992; Petschick et al., 1996). XRD measurements were conducted with an automated Philips PW1710 powder diffraction system, using CuKa radiation (40 kV, $40 \mathrm{~mA})$. Each sam- 
Table 1. Clay and heavy minerals from AND-1B core assigned to their likely source area.

\begin{tabular}{|c|c|c|}
\hline Mineral & Source rocks & Provenance \\
\hline Illite & $\begin{array}{l}\text { Granitoids (Granite-Harbour Intrusive Complex), } \\
\text { metasediments (Koettlitz Group) }\end{array}$ & TAM-BC \\
\hline Smectite & $\begin{array}{l}\text { Volcanic rocks (McMurdo Volcanics), Ferrar } \\
\text { dolerites (Ferrar Group) }\end{array}$ & MVG-FG \\
\hline Chlorite & $\begin{array}{l}\text { Granitoids (Granite-Harbour Intrusive Complex), } \\
\text { metasediments (Koettlitz Group) }\end{array}$ & TAM-BC \\
\hline Kaolinite & Sedimentary rocks (Beacon Supergroup) & TAM-BS \\
\hline Olivine & Alkali volcanic rocks (McMurdo Volcanics) & MVG \\
\hline Titanaugite & Alkali volcanic rocks (McMurdo Volcanics) & MVG \\
\hline Low-Ca Augite & Ferrar dolerites (Ferrar Group) & TAM-FG \\
\hline Enstatite & Ferrar dolerites (Ferrar Group) & TAM-FG \\
\hline Glass & Volcanic rocks (McMurdo Volcanics) & MVG \\
\hline Kaersutite & $\begin{array}{l}\text { Trachytes, basalts and trachyandesites (McMurdo } \\
\text { Volcanics) }\end{array}$ & MVG \\
\hline Hornblende & $\begin{array}{l}\text { Amphibolites (Koettlitz Group); granitoids } \\
\text { (Granite-Harbour Intrusive Complex) }\end{array}$ & TAM-BC \\
\hline Garnet & Metasediments and marbles (Koettlitz Group) & TAM-BC \\
\hline Apatite & $\begin{array}{l}\text { Angular: basalts and phonolites (McMurdo Volcanics) } \\
\text { Rounded: sedimentary rocks (Beacon Supergroup) }\end{array}$ & $\begin{array}{l}\text { MVG } \\
\text { TAM-BS }\end{array}$ \\
\hline Titanomagnetite & Basalts and phonolites (McMurdo Volcanics) & MVG \\
\hline
\end{tabular}

MVG = McMurdo Volcanic Group; TAM = Transantarctic Mountain; FG = Ferrar Group; BC = Basement Complex; BS = Beacon Supergroup.

ple was analyzed between $2^{\circ}$ and $40^{\circ} 2 \theta$, with a step size of $0.02^{\circ} 2 \theta$, in the air-dry state and after ethylene glycol solvation. Additionally, a slow scan, between $23^{\circ}$ and $25.5^{\circ} 2 \theta$, with a step size of $0.005^{\circ} 2 \theta$, was performed on the glycolated samples to obtain a better resolution of the chlorite-kaolinite twin peaks. Diffractograms were processed using the "MacDiff" software (Petschick, University of Frankfurt, Germany, http://servermac.geologie.uni-frankfurt.de/Staff/Homepages/Petschick/RainerE.html\#MacDiff ) to determine the abundance of the main clay minerals (smectite, illite, chlorite and kaolinite) using the weighting factors of Biscay (1965). Clay mineral percentage standard deviations were calculated using results of ten diffractograms obtained from ten oriented mounts prepared from one single sample. Standard deviations are: illite $\pm 1 \%$, smectite $\pm 1 \%$, chlorite $\pm 2.5 \%$ and kaolinite $\pm 2 \%$.

The heavy mineral separation from the medium-fine sand fraction was carried out in a centrifuge using a sodium polytungstate solution with a density of $2.93 \mathrm{~g} \mathrm{~cm}^{-3}$ (Callahan, 1987). The heavy mineral types occurring in the samples were recognized under the optical microscope. Then heavy minerals from each sample were mounted onto a glass slide, carbon coated and viewed using a scanning electron microscope (Philips XL30 SEM) equipped with an energy dispersive X-ray detection system (EDAX). Following the method proposed by Hanan and Totten (1996), we determined each mineral through semiquantitative chemical analyses. The grain morphology allows to establish the crystallinity versus glassy nature of the grains; the chemical analyses allows to determine the mineral composition, making it possible to refine the distinction among pyroxenes (Fe-Mg pyroxenes, diospide, Titanoaugites), amphiboles, oxides. The abundance of each mineral was calculated as a percentage of the total grains $(n=250)$ counted for each samples. Errors were estimated from repeated measurements $(n=3)$ on three separates and they are always lower than 5\%. Semi-quantitative chemical analyses for each mineral species have been obtained; although the errors are higher than the errors for analyses obtained on a polished mineral surface, the analyses can be compared and they are representative of compositions for each mineral species. Although semiquantitative, EDS analyses rarely lead to misclassification of grains. As an example, since SEM does not provide structural information, mis-classification can occur
Table 2. Representative, qualitative chemical analyses of the main silicates in the heavy mineral sand fraction from MIS samples.

\begin{tabular}{lcccccccc}
\hline & $\begin{array}{c}\text { Olivine } \\
\text { (MGV) }\end{array}$ & $\begin{array}{c}\text { Cpx } \\
\text { (MGV) }\end{array}$ & $\begin{array}{c}\text { Cpx } \\
\text { (TAM) }\end{array}$ & $\begin{array}{c}\text { Opx } \\
\text { (TAM) }\end{array}$ & $\begin{array}{c}\text { Kaers } \\
\text { (MGV) }\end{array}$ & $\begin{array}{c}\mathrm{Hbl} \\
\text { (TAM) }\end{array}$ & $\begin{array}{c}\text { Grt } \\
\text { (TAM) }\end{array}$ & $\begin{array}{c}\text { Grt } \\
(\text { TAM) }\end{array}$ \\
\hline $\mathrm{SiO}_{2}$ & 39.62 & 48.88 & 52.75 & 55.33 & 41.7 & 48.23 & 38.81 & 41.65 \\
$\mathrm{TiO}_{2}$ & 0.19 & 2.57 & 0.55 & 0.35 & 3.77 & 0.69 & 0.92 & 0.28 \\
$\mathrm{Al}_{2} \mathrm{O}_{3}$ & 0.23 & 6.71 & 2.29 & 1.47 & 14.94 & 11.08 & 20.6 & 23.04 \\
$\mathrm{FeO}$ & 15.84 & 5.89 & 10.2 & 10.82 & 12.32 & 14.7 & 14.95 & 20.07 \\
$\mathrm{MnO}$ & 0.52 & 0.16 & 0.87 & 0.72 & 0.38 & 0.65 & 0.63 & 0.85 \\
$\mathrm{MgO}$ & 42.77 & 14.45 & 12.74 & 28.28 & 11.62 & 12.06 & 2.46 & 11.79 \\
$\mathrm{CaO}$ & 0.36 & 20.92 & 19.2 & 2.35 & 9.91 & 9.23 & 19.67 & 1.9 \\
$\mathrm{Na} \mathrm{O}_{2}$ & 0.37 & 0.42 & 1.24 & 0.44 & 4.4 & 2.42 & 1.07 & 0.23 \\
$\mathrm{~K}_{2} \mathrm{O}$ & 0.1 & 0 & 0.17 & 0.23 & 0.94 & 0.95 & 0.89 & 0.18 \\
$\mathrm{Si}$ & 1 & 1.8 & 2 & 2 & 6 & 6.9 & 3 & 3.1 \\
$\mathrm{Al}$ & 0 & 0.3 & 0.1 & 0.1 & 2.6 & 1.9 & 1.9 & 2 \\
$\mathrm{Ti}$ & 0 & 0.1 & 0 & 0 & 0.4 & 0.1 & 0.1 & 0 \\
$\mathrm{Fe}$ & 0.3 & 0.2 & 0.3 & 0.3 & 1.5 & 1.8 & 1 & 1.2 \\
$\mathrm{Mg}$ & 1.6 & 0.8 & 0.7 & 1.5 & 2.5 & 2.6 & 0.3 & 1.3 \\
$\mathrm{Mn}$ & 0 & 0 & 0 & 0 & 0.1 & 0.1 & 0 & 0.1 \\
$\mathrm{Ca}$ & 0 & 0.8 & 0.8 & 0.1 & 1.5 & 1.4 & 1.6 & 0.2 \\
$\mathrm{Na}$ & 0 & 0 & 0.1 & 0 & 1.2 & 0.7 & 0.2 & 0 \\
$\mathrm{~K}$ & 0 & 0 & 0 & 0 & 0.2 & 0.2 & 0.1 & 0 \\
$\mathrm{O}$ & 4 & 6 & 6 & 6 & 23 & 23 & 12 & 12
\end{tabular}

Analyses are given in oxide wt.\% and recalculated on the basis of negative charges (indicated by the 0 number). MGV: Mcmurdo Volcanic Group; TAM: Transantarctic Mountains; Cpx (MGV): Ti/Al rich clinopyroxene from volcanic rocks of the Mcmurdo Volcanic Group; Cpx (TAM): clinopyroxene from the Ferrar dolerites cropping out in the Transantarctic Mountains; Opx (TAM): Mg-rich pyroxene from the Ferrar dolerites cropping out in the Transantarctic Mountains; Kaers (MGV): Ti-rich amphibole from volcanic rocks of the Mcmurdo Volcanic Group; Hbl (TAM): hornblende from the Ferrar dolerites cropping out in the Transantarctic Mountains; Grt (TAM): garnets from the medium grade metamorphic rocks cropping out in the Transantarctic Mountains.

when glass fragments have a similar composition to feldspars; however, this is not our case: feldspars and alkaline glass are not comprised in the heavy mineral group.

Discriminant function analysis (DFA) determines a linear combination of variables (in this study, clay and heavy mineral contents). Variation of one or more of these variables allow the discrimination of predetermined groups that were defined following the facies description given by the ANDRILL sedimentology team (Krissek and the ANDRILL-MIS Science Team, 2007). The computer program Discriminant of the SPSS 10.0 software package allows the linear combination of variables; these discriminant functions can be used to determine the likelihood of classification of the samples into the pre-defined groups. Variables that best discriminate between groups have been determined (Stokes and Lowe, 1988).

\section{Results}

\subsection{Clay minerals}

The major clay minerals in the Pleistocene section of the AND-1B core are illite and smectite. Chlorite is rarely more than $25 \%$ and kaolinite is absent or present in trace amounts $(<7 \%)$. Illite content ranges between ca. 30 and $80 \%$ and it is negatively correlated $\left(R^{2}=-0.86\right)$ with smectite.

Figure 2 shows the down-core clay mineral variations. Between 9.9 and 30.11 mbsf illite decreases while smectite and chlorite increase; however, only three samples were taken from this interval. Between 31 and 49.5 mbsf illite and smectite contents show strong fluctuations, but illite is always lower than $60 \%$ and smectite often higher than $30 \%$; chlorite content usually ranges between 15 and 30\%. Below $50 \mathrm{mbsf}$, illite content is higher than $60 \%$, whereas smectite is lower than $30 \%$; both minerals show less pronounced fluctuations with respect to the upper section. Chlorite varies between 10 and $25 \%$. Kaolinite is higher in the lower section. 
Figure 3. SEM-BSE images of the most abundant heavy minerals recovered in the AND-1B samples.

a: ca. $50 \mu \mathrm{m}$ large olivine $(\mathrm{Ol})$ crystal with smaller olivine, titanomagnetite ( $\mathrm{Ti}-$ Mag) and clinopyroxene (Cpx) crystals growing on the top of it (MVG provenance);

b: euhedral $\mathrm{Ti}-\mathrm{Al}$ rich clinopyroxene crystal (MVG provenance);

c: a volcanic rock fragment (MVG provenance) comprised of vescicular glass $(\mathrm{gl})$, olivine $(\mathrm{Ol})$ and titanomagnetite (Ti-Mag);

d: euhedral apatite crystal (Ap; MVG provenance);

e: a rounded garnet crystal (Grt) with visible crystal faces (TAM provenance);

$\mathrm{f}$ : a sub-rounded pyroxene crystal with smooth edges and visible cleavage planes (TAM provenance);

g: rounded orthopyroxene crystal (Opx) with smooth edges and visible cleavage planes (TAM provenance);

$h$ : a sub-angular apatite crystal showing fracture plates (white arrows) (TAM provenance).
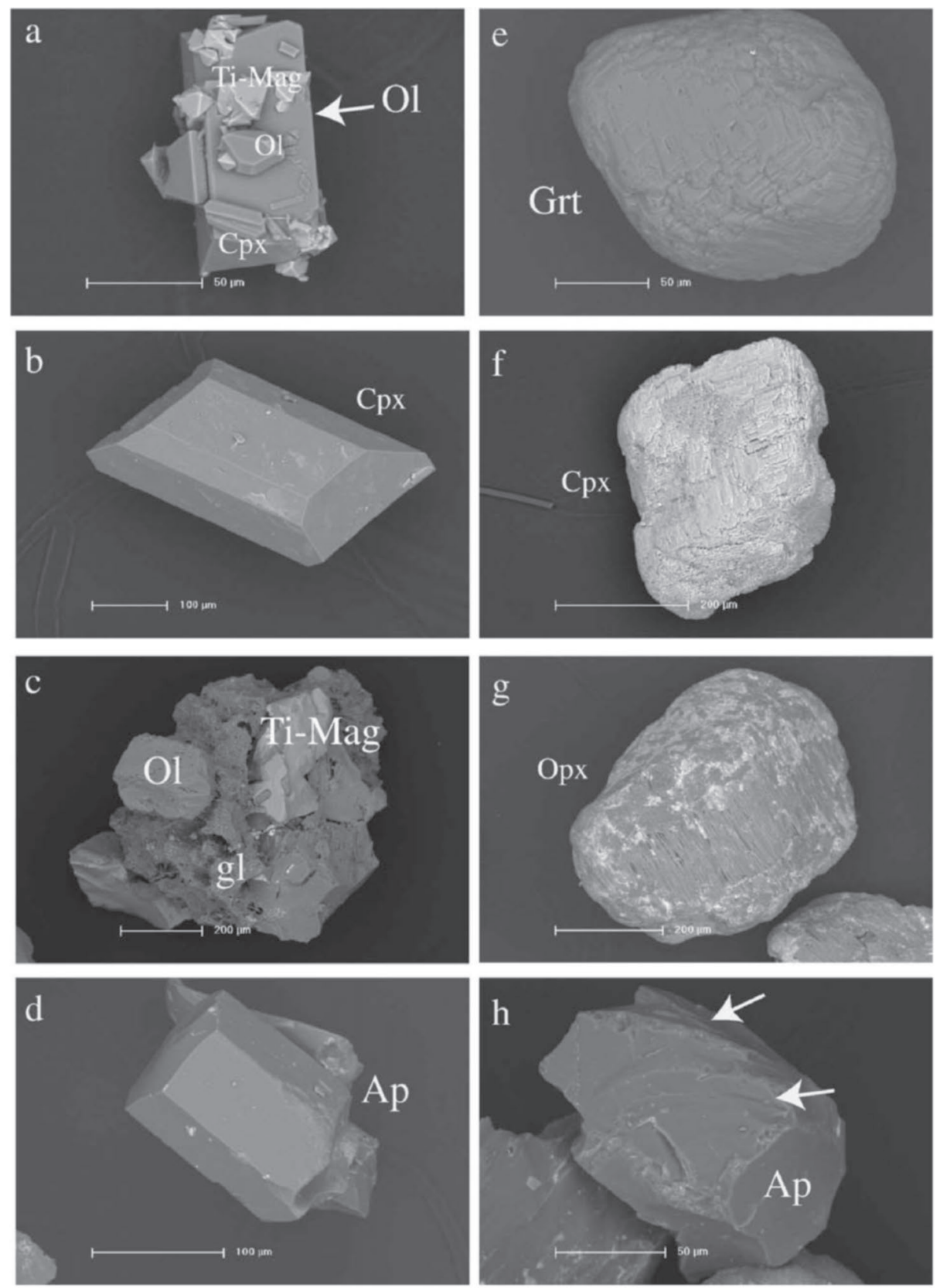

In Pleistocene Antarctic ( $<1 \mathrm{Ma}$ ) marine sediments, detrital clay minerals are considered to indicate source rocks, as well as transport and depositional mechanisms (Ehrmann et al., 1992; Diekmann et al., 1999). In the Ross sea sediments, smectite derives from weathering of volcanic rocks (Chamley, 1989; Ehrmann et al., 1992). The most probable source rocks are the lavas of the MVG (Table 1), but dolerites and basalts from the Ferrar Supergroup may be a source, too. Illite (i.e., biotite and muscovite) and chlorite derive from the physical degradation of rocks rich in these two phases such as metamorphic and intrusive felsic rocks. Muscovitic illites can also form as alteration of alkali feldspars and plagioclase in intrusive and volcanic rocks. Schists, amphibolites, gneisses of the Koettlitz Group and granites s.l. of the GHI complex represent the source rocks for illites and chlorite (Table 1). In the present Antarctic environment kaolinite, which forms from intense chemical weathering of parent rocks, represents the product of reworking of older sediments and soils. It is present in sedimentary rocks of the Beacon Supergroup which are the most probable source for this mineral (Table 1$)$.

\subsection{Heavy minerals}

The heavy mineral assemblages are dominated by olivine and pyroxenes, whereas amphiboles, spinels, other Fe-oxides, and stable minerals (epidote, garnet, apatite, aluminosilicates) are present in minor amounts only.

Olivine grains have a homogeneous, $\mathrm{Mg}$-rich $\left(\mathrm{Fo}_{84}\right.$, see Table 2) chemical composition. They often occur as euhedral crystals (Figure 3a) rarely showing hacksaw terminations which indicate corrosion.

Pyroxenes can be divided into three main groups considering their chemical composition. Titanoaugites (Table 2, Figure 4) are the most abundant pyroxenes and occur as euhedral crystals of variable size (Figure 3a, b).

Low-Ca augites and enstatitic orthopyroxenes (Table 2, Figure 4) usually show a rounded/sub-rounded shape with smooth edges and clearly visible cleavage planes (Figure 3f, g).

Glass is commonly excluded from the heavy mineral group; yet in the present study, vesicular glass fragments have been found and counted, because they are associated 


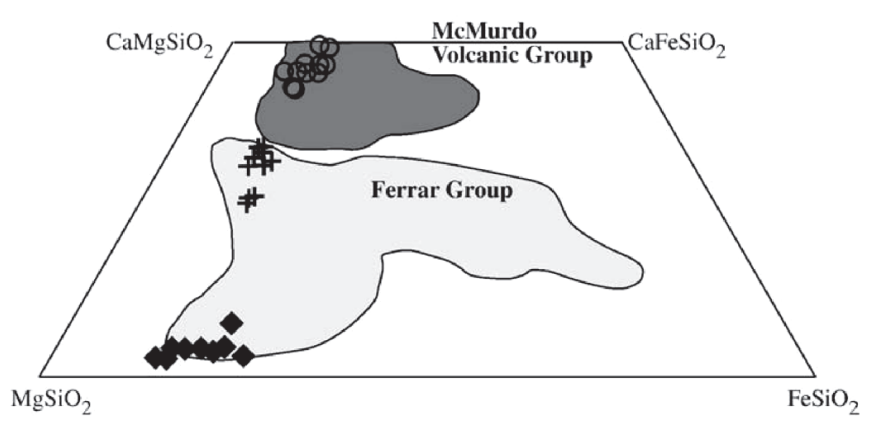

Figure 4. Chemical compositions of pyroxenes from the MIS samples. Fields representing chemical composition of pyroxenes from the McMurdo Volcanic Province (after Gamble et al., 1986) (dark grey) and from the Ferrar Province (after Haban and Elliot, 1958) (light grey). Open circles: Ti-Al rich clinopyroxenes from the MGV; crosses: clinopyroxenes from the Ferrar Group; filled diamonds: Mg-rich pyroxenes from the Ferrar Group.

with or include heavy mineral phases such as titanomagnetite, olivine, pyroxene (Figure 3c).

Two types of amphiboles have been distinguished: kaersutite and common hornblende (Table 2).

Garnet grains have a chemical composition varying from the pyrope-almandine member to grossular (Table 2). They occur with rounded/sub-rounded shapes and smooth edges (Figure 3e). Apatite grains occur with two types of morphology: euhedral crystals (type 1) and sub-rounded/sub-angular-shaped crystals with fracture plates (type 2) (Figure $3 \mathrm{~d}, \mathrm{~h}$ ). An aluminosilicate (kyanite, sillimanite, andalusite) has been also recognized. Rhönite grains are rare, but occur throughout the core, whereas magnesite was found only in two samples at 68 and 69 mbsf.
Figure 5 shows the down-core variations of the main heavy mineral phases counted in the core. The stable mineral group comprises garnets, apatite, sphene, aluminosilicates, zircon, and rutile; these last two phases are extremely rare. Based on olivine, titanoaugite, kaersutite, and spinel (mainly titanomagnetite) contents the core can be divided into two sections. The upper part (down to $49.5 \mathrm{mbsf}$ ) is characterized by percentages of olivine and titanoaugite between 20 and $45 \%$; spinel content reaches up $20 \%$, but is mainly around $10 \%$. Below 49.5 mbsf titanoaugite becomes the most abundant phase with values between 32 and $65 \%$ with only one exception (sample at $85.01 \mathrm{mbsf}$ ). Low-Ca augites and orthopyroxenes show contents which do not exceed 20 and $10 \%$, respectively, down to $49.5 \mathrm{mbsf}$. The sample at 42.48 mbsf has an anomalously high (28\%) content of augite for this interval. Notably, this sample is the one with the highest content of type 2 apatite grains. Below $58 \mathrm{mbsf}$, the content of these two pyroxenes, although variable, is on average higher with respect to the upper section; it decreases from ca. 80 mbsf down to 90 mbsf. Stable minerals are scarce throughout the core. Their content is lower than 5\% from the top to 49.5 mbsf and from 80 to $90 \mathrm{mbsf}$, but increases slightly between 58 and 80 mbsf.

Heavy minerals are sensitive indicators of provenance but weathering in the source areas, transportation, deposition and diagenesis can mask the provenance signal (Morton, 1985). However, Pleistocene AND-1B sediments are derived from areas subjected to physical weathering, and no major changes in the weathering regime seem to have occurred during that period of time. Unstable minerals, such as amphiboles and pyroxenes (Morton, 1985), are abundant and present throughout the core; they do not show evidence of chemical weathering like etching or skeletal habits.
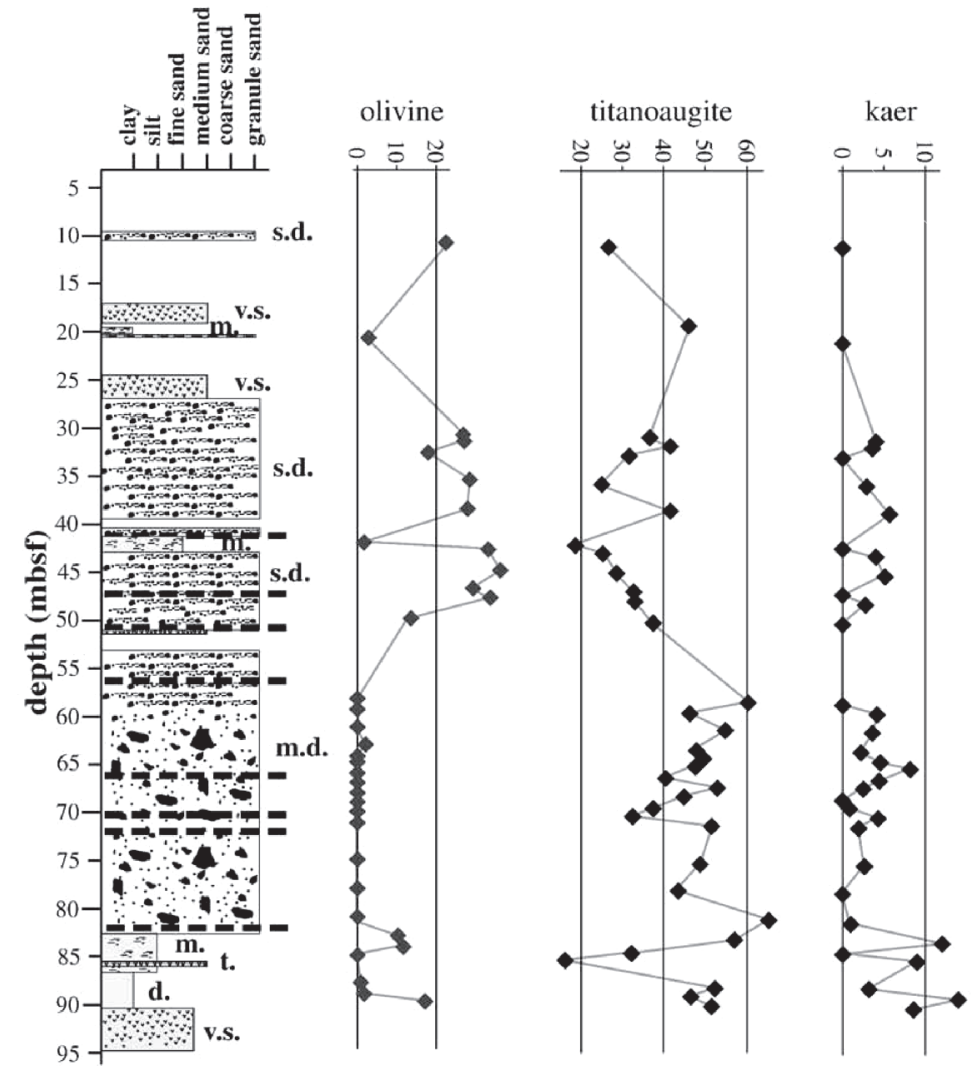

$\%$
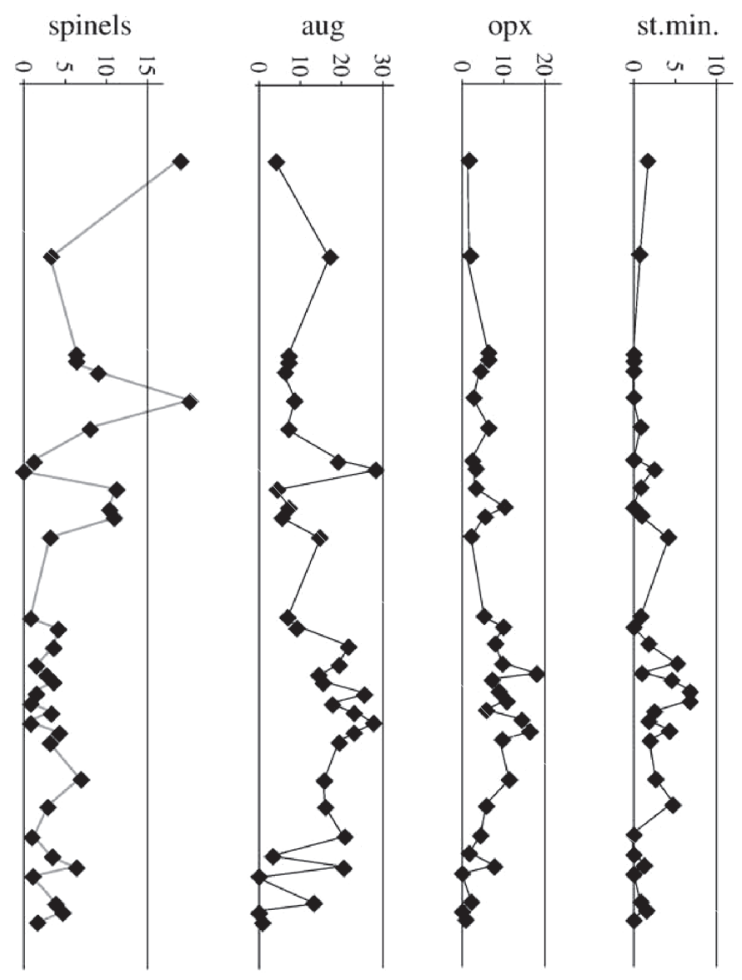

Figure 5. Down-core variations of the main heavy mineral phases. Symbols as in Figure 2. kaer: kaersutite; aug: low-Ca augites; opx: Mg-rich orthopyroxenes; st. min.: stable minerals (garnets, apatite, sphene, aluminosilicates, zircon, and rutile). 
Figure 6. Heavy mineral contribution from each provenance area. McMurdo Volcanic Group (MVG): dark grey; Transantarctic Mountains (TAM): light grey. Symbols as in Figure 2.
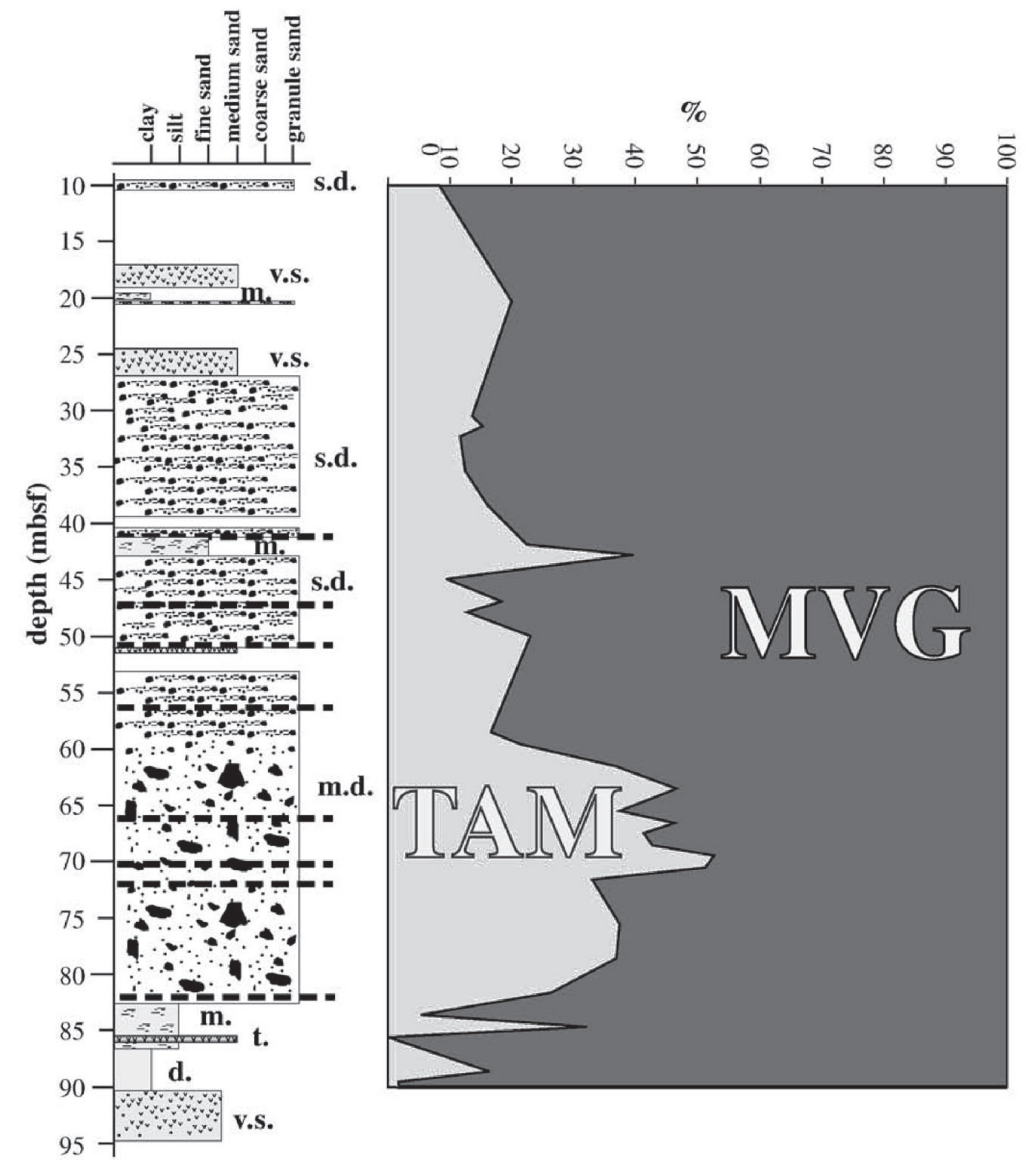

Consequently, weathering does not control the heavy mineral proportions in the samples. Density is the most important control on the hydraulic behaviour of heavy minerals, mainly considering minerals with similar grain morphology. We can assume that distribution of minerals with comparable densities (forsterite, enstatite, augite) is not affected by hydraulic sorting. As it will be discussed in the next section, the main heavy mineral variation in the AND-1B core is not related to sedimentary facies change. Yet, some variations do occur at sedimentary facies boundaries, but they are mainly linked to those minerals with analogous hydraulic behaviour. We conclude that parent rocks provide initial control on heavy mineral association in the AND-1B sedimentary sequence, and that variations in these assemblages are mainly caused by variations in ice drainage. We present possible source rocks for the heavy minerals in Table $1 . \mathrm{Fo}_{84}$ olivine grains derive from alkaline volcanic rocks of the McMurdo Volcanic Group (Leung and Trevis, 1987). Clinopyroxenes with a titanoaugite composition (Figure 4) represent the most abundant phenocrysts in the MVG lavas (George, 1989). Their euhedral shape in the AND-1B sediments indicates that they did not experience long-distance transport processes. In contrast, low-Ca augites and orthopyroxenes are supplied by the Ferrar dolerites cropping out in the Transantarctic Mountains. The augites usually show a subrounded shape indicating prolonged transport. Volcanic glass fragments, which often bear olivine and augite grains, can be correlated with the eruptions of the Erebus Volcanic Province (MVG) and redeposited MVG material in the MIS sedimentary basin. Kaersutite is characteristic of basaltic volcanic rocks and is a component of trachytes, basalts and trachyandesites of the MVG. On the other hand, common hornblende is a component of many metamorphic and magmatic rocks; likely source rocks for this mineral are amphibolites of the Koettlitz Group (TAM) and granitoids of the Granite Harbour Intrusive Complex (TAM). Pyropealmandine and grossular garnets occur in metasediments and marbles of the Koettlitz Group (TAM). Angular, subhedral apatite grains are probably supplied by volcanic rocks of the MVG; subrounded apatite grains with signs of prolonged transport could be recycled from the sedimentary rocks of the Beacon Supergroup. Titanomagnetite and rhönite are typical accessory constituents of Mt. Erebus phonolite (Kyle and Price, 1975).

\section{Discussion}

Illite is an abundant clay mineral in the AND-1B Pleistocene sediments as it is in other Pleistocene sedimentary sequences on the Antarctic continental shelf and rise (Lucchi et al., 2002; Junttila et al., 2005; Damiani et al., 2006). The negative correlation between illite and smectite indicates that mixing of sediments from two different source areas occurred: TAM source rocks and MVG source rocks. Considering the downcore clay mineral distribution (Figure 2), two units can be distinguished: Unit 1 (down to $49.5 \mathrm{mbsf}$ ) is characterized by strong fluctuations in the illite/smectite ratio. Unit 2 (50$90 \mathrm{mbsf}$ ) is characterized by a constant illite/smectite ratio.

Following the heavy mineral classification as a function of source rocks, heavy minerals have been assigned to the two possible source areas, TAM and MVG. Figure 6 shows the down-core variation of these two groups. MVG minerals are usually more abundant than TAM minerals. A maximum input of minerals from TAM occurs between 60 and 80 mbsf, where massive diamicton occurs. Another relative maximum of TAM minerals is at ca. 41-42 and at 85 mbsf, where layers of glaciomarine sediment occur. 


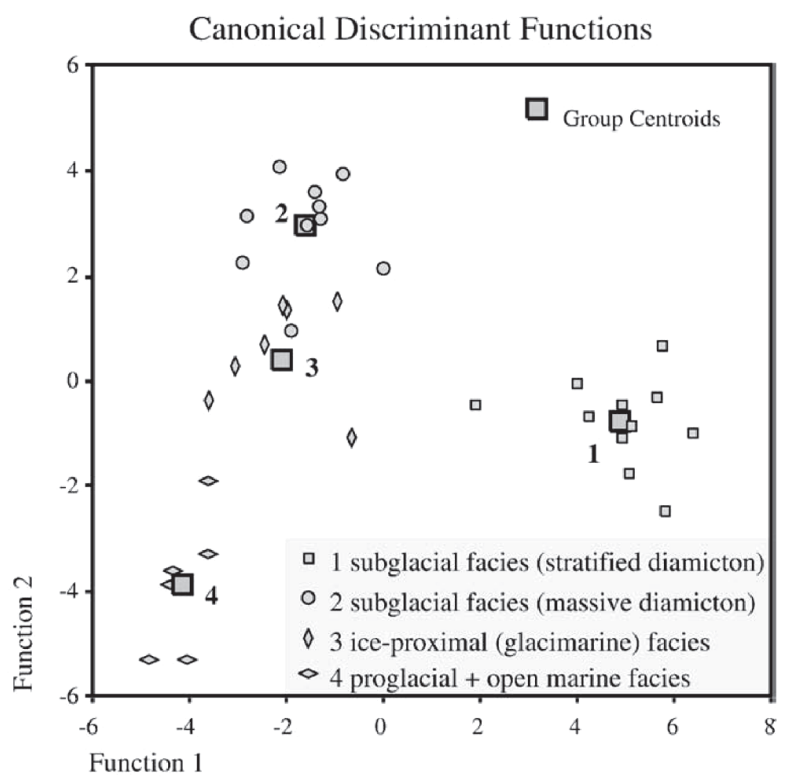

Figure 7. Plot of discriminant scores along Function I versus Function II, to discriminate samples belonging to different sedimentary facies.

Strong fluctuations of clay and heavy minerals derived from the two groups of source rocks occur in the AND$1 \mathrm{~B}$ core (Figure 2 and Figure 5). For this reason, a statistical analysis of all the available mineralogical data (clay and heavy minerals) have been performed to investigate the possible correlations between these two sets of data and between mineralogical composition and sediment facies.

The discriminant function analysis (DFA) revealed that the individual samples can be classified into four pre-defined groups. The four groups have been defined based on the stratigraphical position of the samples and the facies of the host sediments: group 1 refers to stratified diamicton above 50 mbsf; group 2 refers to massive diamicton below 50 mbsf; group 3 comprises sediments deposited in an iceproximal environment; group 4 comprises sediments deposited in an open-marine environment ("open marine") distal from the grounding line, below 80 mbsf. The results of DFA are illustrated in the territorial map (Figure 7) showing the clustering of samples in the pre-defined groups, and in Table 3 which reports the coefficients for each variable in the three functions and the structure matrix.

Function I correctly discriminates stratified diamicton from "open marine" facies; massive diamicton and ice-proximal facies sediments are in an intermediate position and overlap. Olivine, spinels, type 1 apatite and smectite have high positive loading on function I (Table 3); kaersutite, lowCa augites, titanoaugite, and illite have a negative loading on function I (Table 3). Function II correctly discriminates diamicton of group 2, "open marine" facies and diamictons of goup 1 plus ice-proximal facies which overlap. LowCa augites, orthopyroxenes and pyrite have a high-positive loading on function II; contrarily, olivine, kaersutite and glass have a negative loading on function II (Table 3).

Combining all the mineralogical data, a further subdivision of the Pleistocene AND-1B sediments becomes obvious. The stratified diamicton is characterized by a high content of MVG-derived minerals, with prevalence of olivine plus spinels. The lower, massive diamicton shows a higher content of TAM-derived minerals; titanoaugites clearly prevail among the MVG minerals. TAM minerals also increase in ice-proximal sediments; "open marine" sediments at the base of the studied sequence are characterized by extremely
Table 3. Discriminant functions: unstandardized discriminant function coefficients used to calculate discriminant scores for the plot in Figure 7.

\begin{tabular}{|c|c|c|c|c|c|c|}
\hline & \multicolumn{3}{|c|}{ Discriminant functions } & \multicolumn{3}{|c|}{ Structure matrix } \\
\hline & 1 & 2 & 3 & 1 & 2 & 3 \\
\hline Olivine & 0.251 & 0.586 & 0.251 & 0.385 & -0.276 & 0.063 \\
\hline Spinels & 0.512 & 0.694 & 0.512 & 0.302 & 0.164 & -0.077 \\
\hline Apatite 1 & 0.458 & 1.061 & 0.458 & 0.157 & -0.083 & -0.087 \\
\hline Smectite & -0.308 & -0.209 & -0.308 & 0.071 & -0.015 & 0.141 \\
\hline Apatite 2 & 1.897 & 1.998 & 1.897 & 0.038 & 0.096 & -0.018 \\
\hline Zircon & -0.115 & -2.511 & -0.115 & 0.020 & 0.060 & -0.060 \\
\hline Orthopyroxene & 0.671 & 1.061 & 0.671 & -0.010 & 0.287 & -0.020 \\
\hline Sphene & 1.311 & 2.821 & 1.311 & -0.014 & 0.147 & -0.027 \\
\hline Fe-oxides & 0.213 & 1.385 & 0.213 & -0.028 & 0.170 & 0.042 \\
\hline Magnesite & -0.295 & -.591 & -0.295 & -0.028 & 0.013 & 0.277 \\
\hline Biotite & -0.037 & 0.923 & -0.037 & -0.054 & 0.189 & -0.171 \\
\hline Garnets & 0.955 & 0.683 & 0.955 & -0.055 & 0.137 & -0.007 \\
\hline Amphibole & 0.157 & 0.868 & 0.157 & -0.056 & 0.074 & 0.314 \\
\hline Chlorite & -0.990 & 0.844 & -0.990 & -0.060 & 0.194 & 0.047 \\
\hline Glass & 0.174 & 0.667 & 0.174 & -0.073 & -0.194 & 0.041 \\
\hline Pyrite & -0.156 & 0.804 & -0.156 & -0.082 & 0.323 & -0.168 \\
\hline Kaolinite & 0.095 & 0.199 & 0.095 & -0.101 & 0.062 & -0.147 \\
\hline Illite & -0.292 & -0.227 & -0.292 & -0.120 & 0.061 & -0.210 \\
\hline Titanoaugite & 0.224 & 0.737 & 0.224 & -0.129 & 0.164 & -0.193 \\
\hline Low-Ca augite & 0.033 & 0.666 & 0.033 & -0.153 & 0.350 & 0.375 \\
\hline Kaersutite & -0.167 & 0.340 & -0.167 & -0.180 & -0.225 & -0.238 \\
\hline (Constant) & 0.738 & -53.568 & 0.738 & & & \\
\hline
\end{tabular}

Structure matrix: pooled within-groups correlations between discriminating variables and standardized canonical discriminant functions.

low TAM mineral content and a relative increase in olivine, kaersutite and glass among the MVG phases.

The clay mineral association is determined both by source rocks and by sedimentary processes. In the stratified diamicton (down to $60 \mathrm{mbsf}$ ) smectite and chlorite, which can be associated to a volcanic source, are more abundant than in the lower massive diamicton (below $60 \mathrm{mbsf}$ ) where contents of illite and kaolinite with a TAM provenance are higher. This evidence agrees with the heavy mineral data. However, the peculiar trends of clay minerals (i.e., strong fluctuations of illite, smectite and chlorite) in the stratified diamictons need an explanation. Stratification, although weak, in diamicton associated with ice-proximal facies probably indicates that during its deposition processes other than sedimentation under grounded ice occurred. During episodes of retreat of the grounding line from the core site, sub-ice shelf currents could have transported and deposited smectite-enriched sediments. As the grounding line re-advanced, subglacial sediments with a higher proportion of illite were deposited. Subglacial deposition of the massive diamicton resulted in a mineralogically homogeneous illite-rich assemblage.

The mineralogical associations in Late Pleistocene AND1B sediments are determined by two factors. Source rocks determine the mineral associations; since Quaternary sedimentary processes in the McMurdo Sound are governed by ice dynamics, we can assume that changes in mineralogy reflect changes in ice provenance. Subglacial versus sub-ice shelf and open-marine sedimentary processes influence the distribution of clay minerals in the sediments.

\section{Conclusions}

Following the ice model proposed by Denton and Hughes $(2000,2002)$, we conclude that sediments at the drill site were nourished by grounded ice coming from the South, which delivered detritus from the McMurdo Volcanic region. When open marine conditions prevailed, sediments from local source (i.e., McMurdo volcanics) were deposited. A transitions from sub-polar to cold, polar conditions is documented 
by the shift from diatomite-dominated sediments (seasonal open-marine conditions) to diamictite-dominated sediments (grounded-ice conditions) at ca. 80 mbsf (Krissek and the ANDRILL-MIS Science Team, 2007; McKay et al., 2009). Licht et al. (2005) recognized in East Antarctica the provenance area of western Ross Sea tills, testifying that West-Antarctic ice streams did not advance into the western Ross Sea during the LGM. Damiani and Giorgetti (2008) presented data in LGM-Holocene sediments from Windless Bight where a shift from TAM- to MVG-derived heavy minerals occurred at the LGM transition. In the AND 1-B core, the transition from MVG- to TAM-dominated heavy mineral assemblages at ca. 80 mbsf marks a transition from open marine to sub-glacial conditions. The older, massive, diamictites have a relative higher content of TAM-derived minerals with respect to the younger, stratified diamictites. A TAM component in the terrigenous sediments testifies that the ice sheet collects debris from the Transantarctic Mountains eroded by the SkeltonMulock glaciers which feed the MRIS south of Minna Bluff. As previous authors hypothesized, the emergence of volcanic centers in the McMurdo area during the Pleistocene (Wilson et al., 2007; Talarico et al., 2009) has contributed to the dilution of the TAM component by sediments derived from the McMurdo volcanics in the younger diamictites. Their mineralogical variability can also be attributed to changes in sedimentary processes. Moreover sediments can be enriched in different phenocrysts, when the ice sheet erodes different lavas.

Acknowledgments - The authors acknowledge the ANDRILL project (a multinational collaboration between. Germany, Italy, New Zealand and United States National Programmes) and the whole ANDRILL MIS Science Team. This research used samples provided by the Antarctic Marine Geology Research Facility (AMGRF) at Florida State University sponsored by the U.S. National Science Foundation.

\section{References}

Angino and Andrews, 1968 - E. E. Angino and R. S. Andrews, Trace element chemistry, heavy minerals and sediment statistics of Weddell Sea sediments, J. Sediment. Petrol. 38 (1968), pp. 634-642.

Barrett and Orombelli, 1999 - P. Barrett and G. Orombelli, Proceedings of the Workshop "Geological Records of Global and Planetary Changes," Terra Antart. Rep. 3 (1999), p. 186.

Bentley, 1998 - C. R. Bentley, Rapid sea-level rise from a West Antarctic ice-sheet collapse: A short-term perspective, J. Glaciol. $\mathbf{4 4}$ (1998), pp. 157-163.

Blank et al., 1963 - H. R. Blank, R. A. Cooper, R. H. Wheeler, and I. A. G. Willis, Geology of the Koettlitz-Blue Glacier Region, southern Victoria Land, Antarctica, R. Soc. N. Z. Trans., Geol. 2 (1963), pp. 79-100.

Biscay, 1965 - P. E. Biscay, Mineralogy and sedimentation of recent deep-sea clay in Atlantic Ocean and adjacent seas and oceans, Geol. Soc. Am. Bull. 76 (1965), pp. 803-832.

Brotzu et al., 1988 - P. Brotzu, G. Capaldi, L. Civetta, L. Melluso, and G. Orsi, Jurassic Ferrar dolerites and Kirkpatrick basalts in northern Victoria Land (Antarctica): Stratigraphy, geochronology and petrology, Mem. Soc. Geol. Ital. 43 (1988), pp. 97-116.

Callahan, 1987 - J. Callahan, A non-toxic heavy liquid and inexpensive filters for separation of mineral grains, J. Sediment. Petrol. 57 (1987), pp. 765-766.

Chamley, 1989 - H. Chamley, Clay Sedimentology, Springer, Berlin (1989), p. 623.

Cook and Craw, 2002 • Y. A. Cook and D. Craw, Neoproterozoic structural slices in the Ross Orogen, Skelton Glacier area, South Victoria Land, Antarctica, N. Z. J. Geol. Geophys. 45 (2002), pp. 133-143.
Damiani and Giorgetti, 2008 • D. Damiani and G. Giorgetti, Provenance of glacial-marine sediments under the McMurdo/Ross Ice Shelf (Windless Bight, Antarctica): heavy minerals and geochemical data, Palaeogeogr. Palaeoclimatol. Palaeoecol. 260 (2008), pp. 262-283.

Damiani et al., 2006 • D. Damiani, G. Giorgetti, and I. Memmi, Clay mineral fluctuation and surface textural analysis of quartz grains in Pliocene-Quaternary marine sediments from Wilkes Land continental rise (East-Antarctica): Paleoenvironmental significance, Mar. Geol. 226 (2006), pp. 281-295.

Denton and Hughes, 2000 • G. H. Denton and T. J. Hughes, Reconstruction of the Ross Ice drainage system, Antarctica, at the Last Glacial Maximum, Geogr. Ann. 82 (2000), pp. 143-166.

Denton and Hughes, 2002 • G. H. Denton and T. J. Hughes, Reconstructing the Antarctic Ice Sheet at the Last Glacial Maximum, Quat. Sci. Rev. 21 (2002), pp. 193-202.

Diekmann et al., 1999 • B. Diekmann, G. Kuhn, A. Mackensen, R. Petschick, D. K. Fütterer, R. Gersonde, C. Ruehlemann, and H.-S. Niebler, Kaolinite and chlorite as tracers of modern and late Quaternary deep water circulaton in the South Atlantic and the adjoining Southern Ocean. In: G. Fischer and G. Wefer, editors, Use of Proxies in Paleoceanogrphy: Examples From the South Atlantic, Springer-Verlag, Berlin (1999), pp. 1-29.

Ehrmann, 1998 - W. Ehrmann, Lower Miocene and Quaternary clay mineral assemblages from CRP-1, Terra Antartica 5 (1998), pp. 613-619.

Ehrmann and Polozek, 1999 • W. Ehrmann and K. Polozek, The heavy mineral record in the Pliocene to Quaternary sediments of the CIROS-2 drill core, McMurdo Sound, Antarctica, Sediment. Geol. 128 (1999), pp. 223-244.

Ehrmann et al., 1992 • W. Ehrmann, K. Melles, G. Kuhn, and H. Grobe, Significance of clay mineral assemblages in the Antarctic Ocean, Mar. Geol. 107 (1992), pp. 249-273.

Elliot et al., 1995 - D. H. Elliot, T. H. Fleming, M. A. Haban, and M. A. Siders, Petrology and mineralogy of the Kirkpatrick basalt and Ferrar dolerites, Mesa Range region, north Victoria Land, Antarctica, Contrib. Antarct. Res. IV. Antarct. Res. Ser. 67 (1995), pp. 103-141.

Findlay et al., 1984 - R. H. Findlay, D. N. B. Skinner, and D. Craw, Lithostratigraphy and structure of the Koettlitz group, McMurdo sound, Antarctica, N. Z. J. Geol. Geophys. 27 (1984), pp. 513-536.

Gamble et al., 1986 • J. A. Gamble, P. J. Barrett, and C. J. Adams, Basaltic clasts from Unit 8. In: P. J. Barrett, editor, Antarctic Cenozoic History from the MSSTS-1 Drillhole, McMurdo Sound, DSIR Bull. vol. 237 (1986), pp. 145-152.

George, 1989 • A. George, Sand provenience. In: P. J. Barrett, editor, Antarctic Cenozoic History from the MSSTS-1 Drillhole, McMurdo Sound, DSIR Bull. vol. 237 (1989), pp. 159-167.

Gunn, 1962 • B. M. Gunn, Differentiation in Ferrar dolerites, Antarctica, N. Z. J. Geol. Geophys. 5 (1962), pp. 820-863.

Haban and Elliot, 1958 - M. A. Haban and D. H. Elliot, Mineral chemistry of the Kirkpatrick Basalt, northern Victoria Land, Antarc. J. U. S. 19 (1958), pp. 30-31.

Hanan and Totten, 1996 - M. A. Hanan and M. W. Totten, Analytical techniques for the separation and SEM identification of heavy minerals in mudrocks, J. Sediment. Res. 66 (1996), pp. 1027-1030.

Harrington, 1965 - H. J. Harrington, Geology and morphology of Antarctica. Biogeography and ecology in Antarctica, Monogr. Biol. 15 (1965), pp. 1-17.

Hillenbrand and Ehrmann, 2005 - C.-D. Hillenbrand and W. Ehrmann, Late Neogene to Quaternary environmental changes in the Antarctic Peninsula region: Evidence from drift sediments, Glob. Planet. Change 45 (2005), pp. 165-191.

Junttila et al., 2005 • J. Junttila, M. Ruikka, and K. Strand, Clay-mineral assemblages in high-resolution Plio-Pleistocene interval at ODP Site 1165, Prydz Bay, Antarctica, Glob. Planet. Change 45 (2005), pp. 151-163.

Kellogg et al., 1996 - T. B. Kellogg, T. J. Hughes, and D. E. Kellogg, Late Pleistocene interactions of East and West Antarctic ice-flow 
regimes: Evidence from the McMurdo Ice Shelf, J. Glaciol. 42 (1996), pp. 486-500.

Krissek and the ANDRILL-MIS Science Team, 2007 • L. Krissek and the ANDRILL-MIS Science Team, Sedimentology and stratigraphy of the AND-1B Core, ANDRILL McMurdo Ice Shelf Project, Antarctica. In: T. Naish, R. Powell and R. Levy, editors, Studies from the ANDRILL McMurdo Ice Shelf Project, Antarctica. Initial Science Report on AND-1B, Terra Antart vol. 14 (2007), pp. 185-222.

Kyle, 1990 - P. R. Kyle, McMurdo Volcanic Group, Western Ross Embayment. In: W. E. LeMasurier and J. W. Thomson, editors, Volcanoes of the Antarctic Plate and Southern Oceans, Antarct. Res. Ser. vol. 48 (1990), pp. 19-25.

Kyle and Price, 1975 - P. R. Kyle and R. C. Price, Occurrence of rhonite in alkali lavas of the McMurdo Volcanic Group, Antarctica, and Dunedin Volcano, New Zealand, Am. Mineral. 60 (1975), pp. 722-725.

LeMasurier and Thomson, 1990 - W. E. LeMasurier and J. W. Thomson, Volcanoes of the Antarctic Plate and Southern Oceans, Antarct. Res. Ser. 48 (1990) 488 pp.

Leung and Trevis, $1987 \bullet$ I. S. Leung and S. B. Trevis, Olivine megacrysts and macrocrysts in an alkaline basalt from Ross Island, Antarctica, Antarct. J. U. S. 22 (5) (1987), pp. 39-41.

Licht et al., 2005 - K. J. Licht, J. R. Lederer, and R. J. Swope, Provenance of LGM glacial till (sand fraction) across the Ross embayment, Antarctica, Quat. Sci. Rev. 24 (2005), pp. 1499-1520.

Lucchi et al., 2002 - R. G. Lucchi, M. Rebesco, A. Camerlenghi, M. Busetti, L. Tomadin, G. Villa, D. Persico, C. Morigi, M. C. Bonci, and G. Giorgetti, Mid-late Pleistocene glaciomarine sedimentary processes of a high-latitude deep-sea sediment drift Antarctic Peninsula Pacific margin, Mar. Geol. 189 (2002), pp. 343-370.

McKay et al., 2009 • R. McKay, G. Browne, L. Carter, E. Cowan, G. Dunbar, L. Krissek, T. Naish, R. Powell, J. Reed, F. Talarico, and T. Wilch, The stratigraphic signature of the Late Cenozoic Antarctic Ice Sheet in the Ross Embayment, Geological Society of America 121 (2009), pp. 1537-1561.

Morton, 1985 - A. C. Morton, Heavy-minerals in provenience studies. In: G. G. Zuffa, editor, Provenance of Arenites, NATO ASI, Ser. C vol. 148 (1985), pp. 249-277.

Naish et al., 2007 - T. R. Naish, R. D. Powell, R. H. Levy, and the ANDRILL MIS Science Team, Studies from the ANDRILL McMurdo Ice shelf Project, Antarctica. Initial Science Report on AND-1B, Terra Antartica 14 (2007), pp. 111-328.
Neumann, 2001 - M. Neumann, Preliminary investigations of heavy mineral record from CRP-3 Drillcore, Victoria Land Basin, Antarctica, Terra Antartica 8 (2001), pp. 517-522.

Petschick et al., 1996 - R. Petschick, G. Kuhn, and F. Gingele, Clay mineral distribution in surface sediments of the South Atlantic: Sources, transport, and relation to oceanography, Mar. Geol. 130 (1996), pp. 203-229.

Polo, 2000 - K. Polozek, Distribution of heavy minerals in CRP2/2A, Victoria land Basin, Antarctica, Terra Antartica 7 (2000), pp. 567-573.

Sandroni and Talarico, 2006 - S. Sandroni and F. Talarico, Analysis of clast lithologies from CIROS-2 core, New Harbour, Antarctica - Implications for ice flow directions during Plio-Pleistocene time, Palaeogeogr. Palaeoclimatol. Palaeoecol. 231 (2006), pp. 215-232.

Smillie, 1992 - R. W. Smillie, Suite subdivision and petrological evolution of granitoids from the Taylor Valley and Ferrar Glacier region, south Victoria Land, Antarct. Sci. 4 (1992), pp. 71-87.

Stokes and Lowe, 1988 - S. Stokes and D. J. Lowe, Discriminant function analysis of Late Quaternary tephras from five volcanoes in New Zealand using glass shard major element chemistry, Quat. Res. 30 (1988), pp. 270-283.

Talarico et al., 2009 • F. M. Talarico, R. M. McKay, R. D. Powell, S. Sandroni, and T. R. Naish, Provenance signatures of the Antarctic Ice Sheets in the Ross Embayment during the Late Miocene to Early Pliocene: The ANDRILL AND-1B core record., Glob. Planet. Change 69 (2009), pp. 103-123.

Wilson and the ANDRILL-MIS Science Team, 2007 • G. Wilson and the ANDRILL-MIS Science Team, Preliminary integrated chronostratigraphy of the AND-1B Core, ANDRILL McMurdo Ice Shelf Project, Antarctica. In: T. Naish, R. Powell, and R. Levy, editors, Studies from the ANDRILL McMurdo Ice Shelf Project, Antarctica. Initial Science Report on AND-1B, Terra Antart. vol. 14 (2007), pp. 297-316.

Wilson et al., 2007 • G. Wilson, D. Damaske, H.-D. Möller, K. Tinto, and T. Jordan, The geological evolution of southern McMurdo Sound - New evidence from a high-resolution aeromagnetic survey, Geophys. J. Int. 170 (2007), pp. 93-100. 